Article

\title{
Evaluation of Thermally Treated Calotropis Procera Fiber for the Removal of Crude Oil on the Water Surface
}

\author{
Larissa Sobral Hilário ${ }^{1}{ }^{\circledR}$, Raoni Batista dos Anjos ${ }^{1}$, Henrique Borges de Moraes Juviniano ${ }^{1}$ and \\ Djalma Ribeiro da Silva ${ }^{1,2, *}$ \\ 1 Postgraduate Program in Petroleum Science and Engineering of the Federal University of Rio Grande do \\ Norte, Av. Sen. Salgado Filho, 3000-Lagoa Nova, Natal, RN 59072-970, Brazil; \\ larissasobralhilario@yahoo.com.br (L.S.H.); raonianjos@gmail.com (R.B.d.A.); \\ henriquebm.eng@gmail.com (H.B.d.M.J.) \\ 2 Institute of Chemistry of the Federal University of Rio Grande do Norte, Address: Av. Sen. Salgado Filho, \\ 3000-Lagoa Nova, Natal, RN 59072-970, Brazil \\ * Correspondence: djalma@ccet.ufrn.br; Tel.: +55-084-99665-2973
}

Received: 17 October 2019; Accepted: 22 November 2019; Published: 25 November 2019

check for updates

\begin{abstract}
Biosorbents have been highlighted as an alternative method for the removal of contaminants from spills or leaks of oil and its derivatives, since they are biodegradable, are highly available, low-cost, and have a good sorption capacity. This research investigated the sorption capacity of Calotropis procera fiber in natura $(\mathrm{CP})$ and thermally treated $\left(150^{\circ} \mathrm{C}\right.$ and $\left.200^{\circ} \mathrm{C}\right)$ for crude oil removal and recovery. The oil sorption tests were carried out in a dry and water (layer) static systems. The assays revealed that $\mathrm{CP}$ fiber has excellent hydrophobic-oil properties and good crude oil sorption capacity, about 75 times its own weight $(76.32 \mathrm{~g} / \mathrm{g})$. The results of the treated fibers, CPT150 and CPT200, showed oil sorption capacities (in $24 \mathrm{~h}$ ) higher than CP, between 94.31-103.37 $\mathrm{g} / \mathrm{g}$ and $124.60-180.95 \mathrm{~g} / \mathrm{g}$, respectively. The results from sample CPT200 showed that it can be an excellent biosorbent for the removal of crude oil and other derivatives due to its high hydrophobicity, great reuse/resorption capacity, and ability to retain oil within the fiber lumens. Thus, it can be applied in the recovery, cleaning, and removal of petroleum products and its derivatives from spills and leaks in the future.
\end{abstract}

Keywords: Calotropis procera; sorption; crude oil

\section{Introduction}

The increase in the production and transportation of petroleum products in recent years increased the risk of oil spill and chemical leaks, since these organic solvents are toxic and can cause serious damages to the environment [1-4]. The impacts of oil pollution are unprecedented, since it disturbs marine life, soil, and air, and it is still a threat to human health with repercussions even in tourism and leisure. In addition to compromising the economy [5], because it is a valuable energy resource, it require demanding a fast and effective recovery, attracting interest from researchers [6,7].

During an event of oil leakage, factors such as composition, density, dispersion, emulsification, and evaporation [8] influence the choice of the technique for fast countermeasures to collect and recover the product in order to minimize its pollution potential [9].

Nowadays, the main technologies used for cleaning oil leaks from the water surface are (i) physical diffusion [10], (ii) in situ burning [11], (iii) bioremediation [12], and (iv) mechanical recovery [13]. Among these, it is important to highlight the mechanical recovery with the use of absorbers for cleaning 
oil spills and insoluble organic solvents in water as an attractive method due to its simplicity and collection integrity not resulting in a secondary pollution [14].

The absorption technology aims to design and develop oil sorbents that have good hydrophobicity, oilphilicity, high absorption capacity, rapid absorption kinetics, biodegradability, and environmental acceptability to absorb the oils from polluted environments [6,14-17].

Generally, sorbents can be classified into three categories: synthetic polymers, inorganic mineral materials, and natural organic materials [18]. A short time ago, a series of synthetic polymers presented high absorption and reuse capacity such as polyurethane [19], formaldehyde-melamine-bisulfite sodium bisulfite [20], and polyvinylalcohol formaldehyde [21]. Despite this, the non-biodegradability, complex preparation process with many stages, results in a costly and limited production for large-scale industrial manufacturing. Inorganic mineral materials, such as silica [22], zeolites [23], perlite [24], sepiolite [25], and vermiculite [26], present low oil absorption capacity and inadequate buoyancy, and are not efficient in removing oil spills.

On the other hand, organic natural materials, such as fibrous organic sorbents, have a relatively higher sorption capacity, an equal density, or, in some cases, are smaller in comparison to inorganic and synthetic sorbents, besides presenting low-cost, biodegradability, and environmental sustainability [27].

In this sense, with an emphasis on green chemistry, there has been a growing interest and increased research in the development of absorbers materials to clean oil spills in recent years, based on natural fibers also called biosorbents, due to their characteristics and advantages [28-31].

Calotropis Procera (CP) is a shrub from the Asclepiadaceae family, which can be found in several regions of the world. It has a natural fiber consisting mainly of cellulose, hemicellulose, lignin, pectin, and wax, as well as hydrophobicity and oleophilic properties. It is biodegradable, light, and has a hollow physical structure [32]. In addition, this fiber has large lumens that contribute to the excellent absorption and retention capacity of oil, making it a promising material for sorption of various oils reported in other studies [33]. Several thermal studies have been conducted to modify characteristics and properties of natural fibers [34-36] in order to increase the sorption performance of oils, becauseit is a simple and low-cost method.

Therefore, the objective of this research was to compare the sorption performance of the $\mathrm{CP}$ in natura fiber, with the fibers obtained by thermal treatments, for crude oil and testing on other types of oils in water, $\mathrm{t}$ so determining that the resulting fiber has a greater capacity and may be used in the future for cleaning, removing, and recovering oils from spills or leaks.

\section{Materials and Methods}

\subsection{Material}

The Calotropis procera $(\mathrm{CP})$ fruits were collected in the coastal region of the Natal municipality, Rio Grande do Norte state, Brazil. The oil used in the sorption experiments was provided by PETROBRAS, Guamaré, Rio Grande do Norte state, Brazil. Moreover, the water of analytical grade was obtained from a reverse osmosis system.

\subsection{Fiber Thermal Treatment}

Initially, the CP fibers were collected and manually separated from the seeds, being dried at room temperature $\left(25 \pm 1^{\circ} \mathrm{C}\right)$ for $24 \mathrm{~h}$. Then, the fibers were thermally treated in a muffle furnace at $150^{\circ} \mathrm{C}$ and $200^{\circ} \mathrm{C}$ for $1 \mathrm{~h}$, and stored in a plastic container and named according to their treatment temperature, CPT150 and CPT200, respectively.

\subsection{Fiber Characterization}

The thermal stability of the CP in natura was evaluated by thermogravimetry analyses (TG) and Derivative Thermogravimetry using a thermogravimetric Analyzer from NETZSCH, TG209F1 Libra (Netsch, Selb, Germany). Approximately $7 \mathrm{mg}$ of sample were used in the TG/Derivative 
Thermogravimetry (DTG) analyses, with a heating rate of $10^{\circ} \mathrm{C} / \mathrm{min}$ and temperature ranging from 28 to $900{ }^{\circ} \mathrm{C}$, under a dynamic nitrogen atmosphere and a flowrate of $20 \mathrm{~mL} / \mathrm{min}$.

The Fourier Transform infrared spectrometry (FT-IR) analysis of the CP, CPT150, and CPT200 fibers were performed using the Frontier instrument (Perkin Elmer, Waltham, MA, USA) at a spectral range between $400-4000 \mathrm{~cm}^{-1}$, with a resolution of $4 \mathrm{~cm}^{-1}$.

The surface morphology of the CP, CPT150, and CPT200 fibers were characterized with a field emission scanning electron microscope (SEM-FEG), Zeiss Auriga 40 (Zeiss, Oberkochen, Germany), with a power of $15 \mathrm{kV}$. The fibers were coated with a gold film by sprinklers.

The contact angle measurement $(\theta)$ of water and oil in samples CP, CPT150, and CPT200 were performed in a Tensiometer, model K100C (Krüss, Hamburg, Germany).

For the recording of microscopic images regarding the lumen and sorvido oil inside, we used a BIO1B binocular biological optical microscope (Bel Photonics, Monza, Italy).

\subsection{Selectivity Assay}

For the selectivity test of the fiber sorption for oil removal, approximately $1 \mathrm{~mL}$ of crude oil was added into $50 \mathrm{~mL}$ of distilled water inside a beaker in order to form an oil layer on the water surface. Then, the fibers were placed in contact with the oil layer, aided by a clamp, in order to record the selectivity of sorption. The crude oil used had a specific gravity of $0,861 \mathrm{~g} / \mathrm{cm}^{3}$ and absolute viscosity of $\eta=73.6 \mathrm{cP}$.

\subsection{Sorption Assay}

The CP, CPT150, and CPT200 samples, $10 \mathrm{~g}$ each, were immersed in a glass vial containing $5 \mathrm{~mL}$ of crude oil, remaining in contact during different time intervals, 5, 20, 40, 60, and $1440 \mathrm{~min}$, at room temperature $\left(25 \pm 2{ }^{\circ} \mathrm{C}\right)$ for the static dry test, while for the sorption tests in oil layer in water, the oil/water volume ratio was 1:5.

After the predetermined times, the fibers were removed with the aid of a clamp, drained on a stainless steel sieve for $5 \mathrm{~min}$, and weighed afterwards. All assays were performed in triplicate under static condition for crude oil, with an absolute viscosity ( $\eta$ ) of $73.6 \mathrm{cP}$.

From the values of initial and final weight of the fibers, the sorption capacity of the specific medium was calculated using Equation (1) [5]:

$$
(S)=\frac{\left(W_{f}-W_{i}\right)}{W_{i}},
$$

where:

$S$ is the sorption capacity in $g$ of oil/g of the sorbent;

$W_{\mathrm{i}}(\mathrm{g})$ is the initial weight of the material dry before the oil sorption; ;

$W_{\mathrm{f}}(\mathrm{g})$ is the final weight of the material after the oil sorption.

The possibility of fiber reuse was evaluated, by compressing the fiber, after oil sorption, being calculated from the weight ratio of the resorption capacity for the initial sorption, and expressed in percentage.

\section{Results}

\subsection{Characterization of the Calotropis Procera Fibers}

\subsubsection{Thermogravimetric Analysis-TG}

The TG and DTG analyses were used to evaluate the thermal stability and the CP decomposition with the increase of temperature. After the analysis of the thermogravimetric curves TG/DTG, temperatures for the thermal treatments of $\mathrm{CP}$ were determined in order to avoid fiber decomposition. 
According to Tu et al. (2018), the thermal treatment favors oil sorption capacity. Consequently, it increases the hydrophobicity and oleophilicity of the fiber.

Figure 1 shows the thermal behavior of $\mathrm{CP}$ fiber in inert nitrogen atmosphere. One can observe four mass loss events for the TG and DTG curves, the first being between $28-100{ }^{\circ} \mathrm{C}$, with a mass loss of approximately $5.9 \%$, mainly related to water (moisture). In the TG and DTG curves (Figure 1), it was possible to observe that the $\mathrm{CP}$ fiber has thermal stability of up to $213^{\circ} \mathrm{C}$.

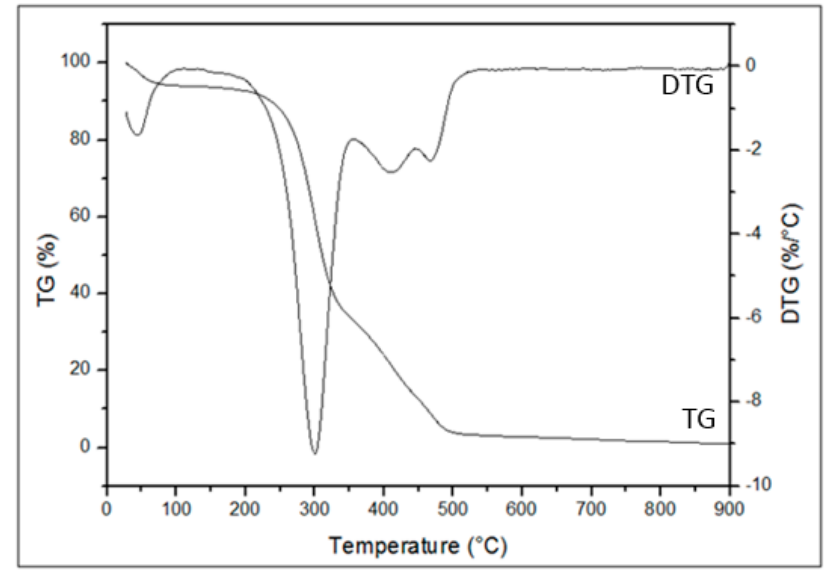

Figure 1. Thermogravimetry (TG) and Derivative Thermogravimetry (DTG) curves of Calotropis procera $(\mathrm{CP})$.

The second event shows a mass loss of $58.8 \%$, between $213^{\circ} \mathrm{C}$ and $354^{\circ} \mathrm{C}$, referring to hemicellulose degradation. According to Yang et al. (2007) [37], the hemicellulose decomposition occurs between 200 and $315{ }^{\circ} \mathrm{C}$. Furthermore, between 354 and $446^{\circ} \mathrm{C}$, one can note a mass loss of $20 \%$, which can be attributed to cellulose degradation. In addition, in the temperature range of $240-400{ }^{\circ} \mathrm{C}$, intense splitting of the cellulose polymeric chains occurs, followed by the onset of lignin decomposition, even with the decomposition of cellulose being the dominant process at this stage [38].

The lignin decomposition occurs gradually from temperatures from 100 to $900{ }^{\circ} \mathrm{C}$ and happens along with the degradation process of hemicellulose and cellulose. This slow decomposition process can be associated to the complex structure of the aromatic rings that constituted lignin [37]. The degradation peak of the remaining lignin can be observed at high temperatures ranging from 400 to $550{ }^{\circ} \mathrm{C}$ [39]. The fourth event observed in the range between $446-516^{\circ} \mathrm{C}$ presented a mass loss of $9.76 \%$, referring to lignin.

The study of the thermal stability for Calotropis procera (CP) performed by Oun and Rhim (2016) [40] presented only two mass loss events. The first event occurred between $60-120{ }^{\circ} \mathrm{C}$ with a mass loss between $4.1-5.6 \%$, mainly due to water loss, and the second and greater mass loss between $200-400{ }^{\circ} \mathrm{C}$, mainly due to degradation of cellulosic materials [41].

\subsubsection{FTIR Analysis}

Figure 2 shows the FTIR spectra of the CPT150 and CPT200 fibers. The band comprised in the region from 3000 to $3350 \mathrm{~cm}^{-1}$ is characteristic of the $\mathrm{O}-\mathrm{H}$ stretch, corresponding to alcohols, phenols, and carboxylic acids present in the fiber composition [37,40,42]. The peak at $2920 \mathrm{~cm}^{-1}$ is attributed to the stretch of bonds $\mathrm{C}-\mathrm{H}$, of $\mathrm{CH}_{2}$, and $\mathrm{CH}_{3}$ aliphatic, characteristic of vegetable waxes, consisting of $\mathrm{N}$-alkanes, fatty acids, aldehydes, ketones, and esters [42,43]. The peaks between 1630 and $1734 \mathrm{~cm}^{-1}$ are characteristic of conjugated and non-conjugated carbonyl $(\mathrm{C}=\mathrm{O})$, respectively, probably originating from carboxylic acids and ketones from the hemicellulose and/or lignin groups [27,44]. A symmetrical flexion of $\mathrm{CH}_{2}$ and elongation of $\mathrm{C}-\mathrm{O}$ and $\mathrm{C}=\mathrm{C}$ characteristic of lignin and cellulose was presented at $1424 \mathrm{~cm}^{-1}$. A flexion of $\mathrm{C}-\mathrm{H}$ is located at $1368 \mathrm{~cm}^{-1}$, while vibrations of $\mathrm{CH}_{2}$ at $1314 \mathrm{~cm}^{-1}$. At $1244 \mathrm{~cm}^{-1}$ there is a peak associated with a double bond $\mathrm{C}=\mathrm{O}$ with stretch, at $1032 \mathrm{~cm}^{-1}$ a simple $\mathrm{C}-\mathrm{O}$ bond 
from hemicellulose and lignin can be observed, while at $896 \mathrm{~cm}^{-1}$ deformation and stretching through $\mathrm{C}-\mathrm{O}-\mathrm{C}, \mathrm{C}-\mathrm{C}-\mathrm{O}$, and $\mathrm{C}-\mathrm{C}-(\mathrm{H})$ was detected [45-47].

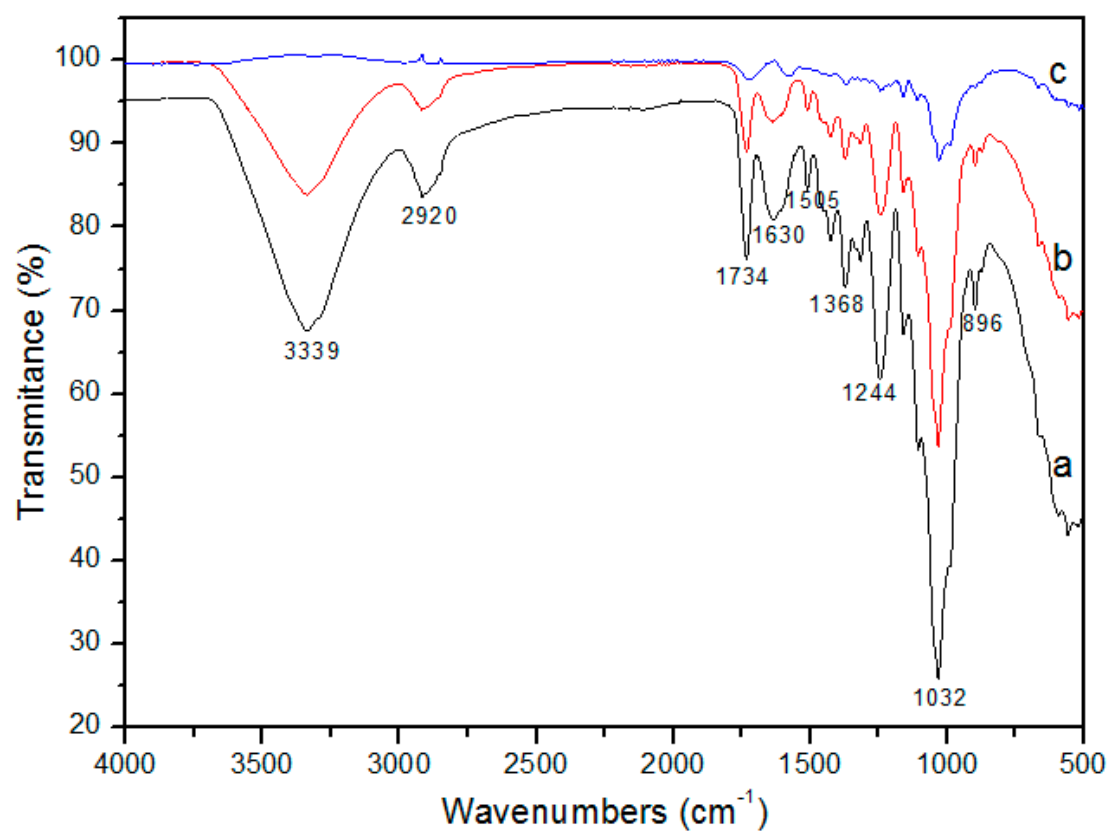

Figure 2. FTIR spectra of (a) CP, (b) CPT150 and (c) CPT200.

When comparing the spectra of the CP fiber with the treated fibers, CPT150 and CPT200, the thermally treated samples showed a decrease in the intensity of the functional groups, including $\mathrm{C}-\mathrm{H}\left(2920 \mathrm{~cm}^{-1}\right), \mathrm{C}=\mathrm{O}\left(1734,1368\right.$, and $\left.1244 \mathrm{~cm}^{-1}\right)$, and $\mathrm{C}-\mathrm{O}\left(1032 \mathrm{~cm}^{-1}\right)$ [48]. According to Tu et al. (2018), such weakening and/or disappearances may be an indication of successful heat treatment [14]. As observed by Draman et al. (2014), attenuations or disappearance of the near peaks corresponding to lignin (1505 and $\left.1597 \mathrm{~cm}^{-1}\right)$ and hemicellulose $\left(1737\right.$ and $1248 \mathrm{~cm}^{-1}$ ) were noted [49].

The broadband region located between 3350 and $3000 \mathrm{~cm}^{-1}$ decreased significantly with temperature increase for the treatments of fibers CP150 $\left(150{ }^{\circ} \mathrm{C}\right)$ and CPT200 $\left(200{ }^{\circ} \mathrm{C}\right)$. In fact, this band is usually associated to $\mathrm{OH}$ stretch vibrations and hydrogen bonds of hydroxyl groups, associated with the general binding by intramolecular and intermolecular hydrogen and free hydroxyl in the cellulose macromolecule. However, the absence of a clear structured form makes it difficult to assign this absorption range, as this peak is also representative of the contribution of free water or linked to the substrate [42].

\subsubsection{Morphological Analysis-SEM-FEG}

Figure 3 presents the micrographs of the CP, CPT150, and CPT200 fibers. It is possible to verify (Figure 3) the presence of hollow lumens in the fibers, which allow the fixation of the oil and retention of inter- and intra-fiber structures [14]. Such microstructure can also help in the buoyancy due to the interior empty spaces being filled with air. 


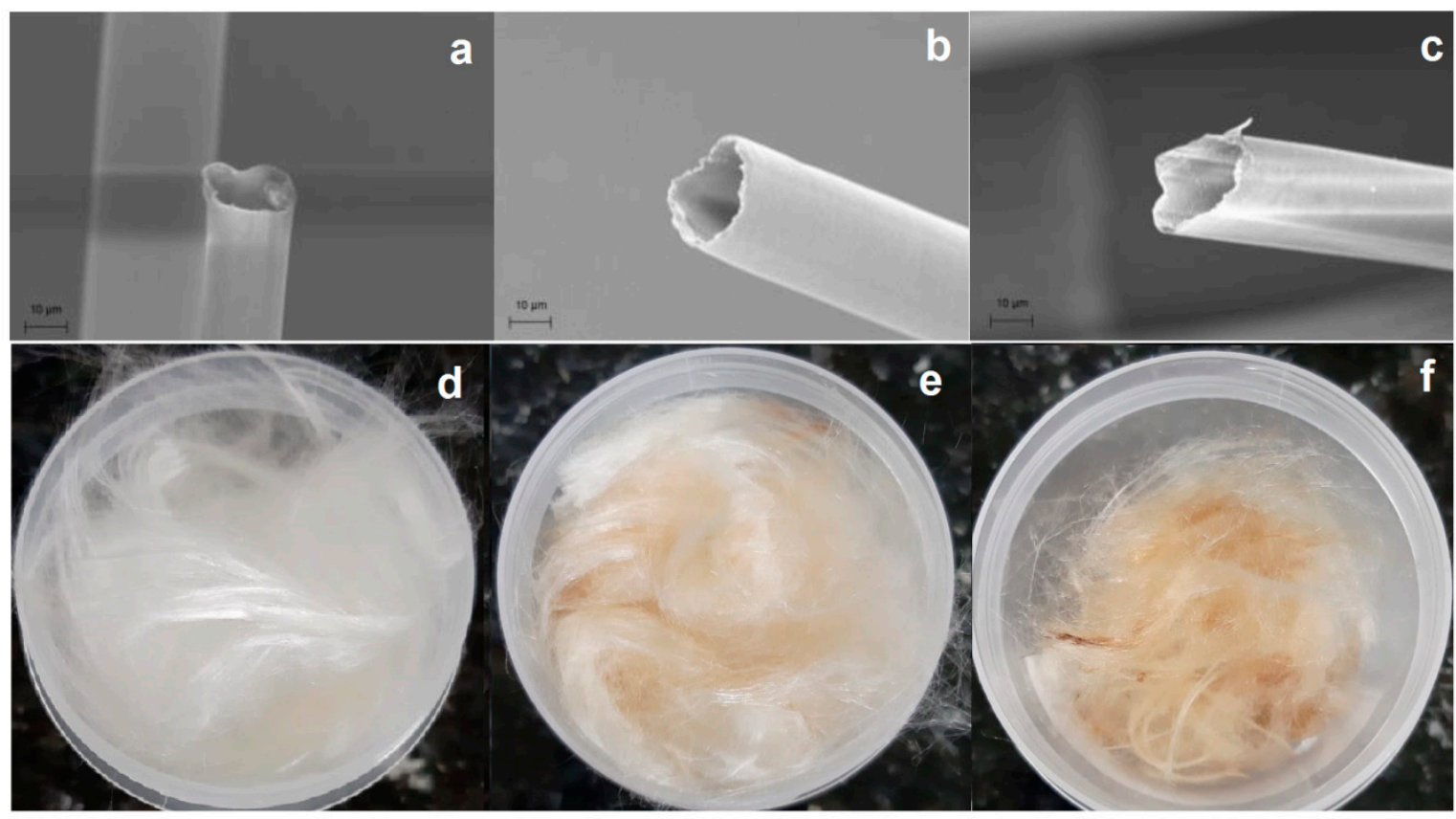

Figure 3. Micrographs obtained by SEM-FEG (a) CP, (b) CPT150, (c) CPT200, (d) CP fiber image, (e) CPT150 fiber image, and (f) CPT200 fiber image.

The micrograph of CP fiber (Figure 3a) shows a smooth surface and with hydrophobic bristly coating the hollow structure, also reported by Thilagavathi et al. (2018) [50]. However, after being subjected to temperatures of $200{ }^{\circ} \mathrm{C}$, the fiber suffered deformation, presenting a more limpid aspect. Such an event can be attributed to the removal of part of the wax, giving more malleability to the fibers.

According to Kalia et al. (2009), although the natural fibers present mostly smooth surfaces, after the thermal treatments, the fibers present a few deep grooves. These grooves are associated with roughness present in the fiber [51], a characteristic that can favor oil sorption.

Figure $3 \mathrm{~d}-\mathrm{f}$ presents, respectively, the appearance of the fiber in the natural state, with the fiber thermally treated at $150{ }^{\circ} \mathrm{C}$ and $200{ }^{\circ} \mathrm{C}$. One can observe an increase in the color intensity of the fiber, a result of the temperature increase used in the heat treatment.

\subsection{Sorption Capacity}

Figure 4a shows the results of the dry sorption tests with a variation of the time from 5 to $1440 \mathrm{~min}$, and as expected, the sorption increases over time. Because the $\mathrm{CP}$ fiber has large lumens coated with waxy material, it has a high oil sorption capacity between $48.61 \mathrm{~g} / \mathrm{g}$ and $74.04 \mathrm{~g} / \mathrm{g}$. In order to achieve a material with better oil sorption capacity (oil), it was proposed to remove part of the hydrophobic wax from the fiber surface through heat treatment. 

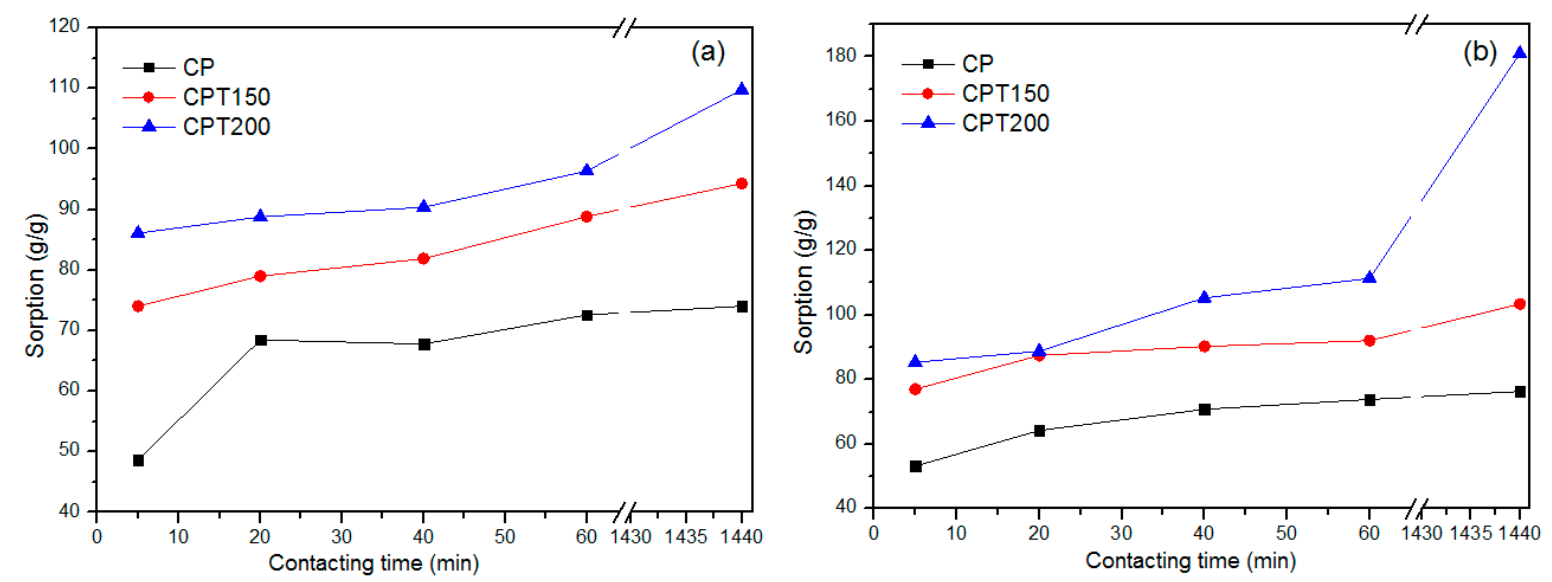

Figure 4. (a) Dry and (b) crude oil layer sorption test for samples CP, CPT150, and CPT200.

As shown in Figure 4a, the dry sorption capacity in the thermally treated fibers at 150 and $200{ }^{\circ} \mathrm{C}$ increased significantly between $15 \%$ and $68 \%$ from the fiber capacity without treatment. The increase in the temperature from 150 to $200{ }^{\circ} \mathrm{C}$ resulted in an increase of the maximum sorption capacity from $94.31 \mathrm{~g} / \mathrm{g}$ to $124.60 \mathrm{~g} / \mathrm{g}$.

In order to evaluate the water sorption capacity, tests were performed using the CP, CPT150, and CPT200 fibers, presented in Figure 5.

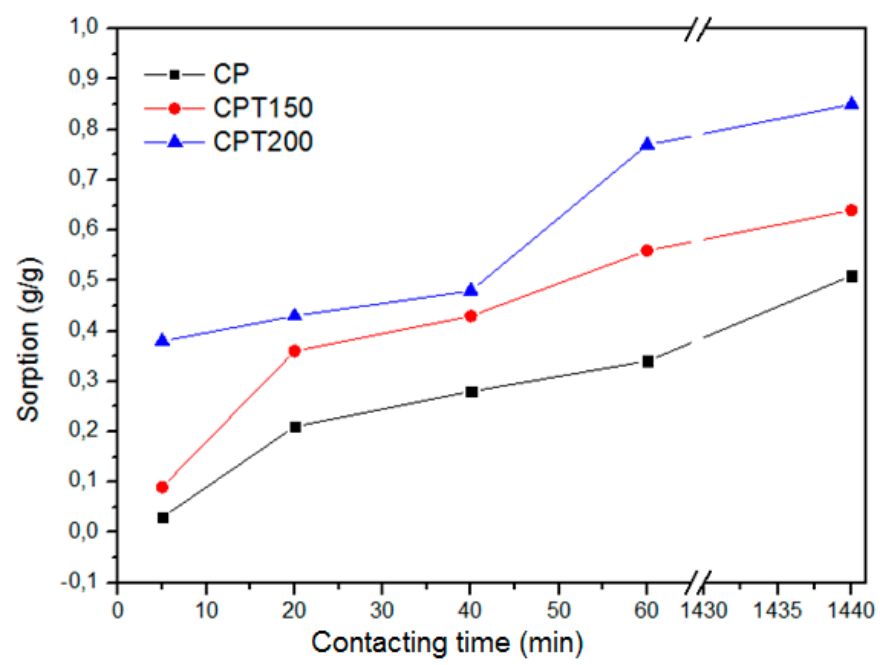

Figure 5. Water sorption test.

As observed (Figure 5), the increase in the fiber treatment temperature results in the increase of water sorption, as expected, due to the removal of the hydrophobic wax material from the fiber surface. The results of the water sorption tests in samples CP, CPT150, and CPT200 reveals that the water ranged from 0.03 to $0.75 \mathrm{~g} / \mathrm{g}$.

In the layer sorption tests (water/oil) the CP, CPT150, and CPT200 fibers presented superior results to the dry tests, with a maximum sorption capacity between $76.32 \mathrm{~g} / \mathrm{g}$ (CP) and $180.95 \mathrm{~g} / \mathrm{g}$ (CPT200). The obtained results are shown in Figure $4 \mathrm{~b}$. The water sorption values were lower than the layer tests results, being insignificant in relation to the amount of absorbed oil.

Based on that, Figure $4 \mathrm{~b}$ revealed that the best conditions of the oil sorption capacity was associated to fiber CPT200, contact time of $1440 \mathrm{~min}$, for both dry and layer (static) systems, respectively, $124.60 \mathrm{~g} / \mathrm{g}$ and $180.95 \mathrm{~g} / \mathrm{g}$, the CP sample obtained an approximate adsorption of 75 times its own weight $(76.32 \mathrm{~g} / \mathrm{g})$. 
Studies performed by Tu et al. (2018) confirmed that carbonization improved the oil sorption capacity for the Calotropis giganteia crude fiber [14]. Similarly, it was proved that the thermally treated $\mathrm{CP}$ considerably favored the oil sorption capacity in relation to $\mathrm{CP}$ in natura, obtaining an increment of about $68.28 \%$ and $137.09 \%$, respectively, for the dry and layer static system. However, it is observed, in general, that the oil sorption capacity of thermally treated CP fiber, as summarized in Table 1, is comparable and even higher than the most reported sorbents in dry tests. In addition, the CPT200 fiber is produced from its precursor material (Calotropis procera) and, consequently, this is a potentially profitable and environmentally friendly material for the removal and recovery of oil in water.

Table 1. Comparison of sorbent materials of oil and organic solvents.

\begin{tabular}{|c|c|c|c|}
\hline Materials & Treatment & Sorption Capacity-Oil & Author \\
\hline Sumauma Fiber & Packed & $\begin{array}{c}36 \mathrm{~g} / \mathrm{g} \text {-Diesel } \\
43 \mathrm{~g} / \mathrm{g}-\text { Hydraulic oil } \\
45 \mathrm{~g} / \mathrm{g}-\text { Motor oil }\end{array}$ & [30] \\
\hline Barley straw & Pyrolyzed & $\begin{array}{c}\text { 5.9-7.6 g/g-Diesel } \\
8.1-9.2 \mathrm{~g} / \mathrm{g} \text {-Heavy oil }\end{array}$ & [36] \\
\hline Silkworm cocoon & Cocoon residues & $\begin{array}{c}42-52 \mathrm{~g} / \mathrm{g} \text {-Motor oil } \\
37-60 \mathrm{~g} / \mathrm{g} \text {-Vegetable oil }\end{array}$ & [52] \\
\hline Cotton fiber & $\begin{array}{c}\text { Loose fiber } \\
\text { Fiber pad shape }\end{array}$ & $\begin{array}{c}22.5 \mathrm{~g} / \mathrm{g} \text {-Lubricating oil } \\
18.43 \mathrm{~g} / \mathrm{g} \text {-Lubricating oil }\end{array}$ & [53] \\
\hline Peat & Granular & 9-12 g/g-Diesel & [54] \\
\hline Cotton fiber & $\begin{array}{l}\text { Carbonized in } \mathrm{N}_{2} \\
\text { atmosphere }\end{array}$ & $\begin{array}{l}32-77 \mathrm{~g} / \mathrm{g} \text {-Crude oil and } \\
\text { solvents }\end{array}$ & [55] \\
\hline Populus fiber & Acetylation & $21.57 \mathrm{~g} / \mathrm{g}$-Corn oil & [56] \\
\hline Clay polymer aerogel & Aerogel & $23.6 \mathrm{~g} / \mathrm{g}$-Dodecane & [57] \\
\hline Celulose aerogel & Methyltrimetoxissyan & $40-95 \mathrm{~g} / \mathrm{g}-\mathrm{Oil}$ & [58] \\
\hline Calotropis gigantea fiber & In natura & $\begin{array}{l}22.6-47.6 \mathrm{~g} / \mathrm{g}-\mathrm{Oil} \text { and } \\
\text { organic solvents }\end{array}$ & [59] \\
\hline Non-polyester fabrics fiber & $\begin{array}{l}\text { (Methylhydro-dimetil) } \\
\text { siloxane }\end{array}$ & $\begin{array}{l}5.52 \mathrm{~g} / \mathrm{g} \text {-Dodecane } \\
10.03 \mathrm{~g} / \mathrm{g} \text {-Motor oil }\end{array}$ & [60] \\
\hline Nanostructured electrospun fibers & Polissulfona/ $\mathrm{NiFe}_{2} \mathrm{O}_{4}$ & $\begin{array}{l}9.20 \mathrm{~g} / \mathrm{g} \text {-Dodecane } \\
15.11 \mathrm{~g} / \mathrm{g} \text {-Motor oil }\end{array}$ & {$[61]$} \\
\hline Calotropis gigantea fiber & Carbonized & $\begin{array}{l}80-130 \mathrm{~g} / \mathrm{g} \text {-Oil and organic } \\
\text { solvents }\end{array}$ & [14] \\
\hline $\begin{array}{l}\text { Mix of cotton, Sumauma, Asclepias } \\
\text { Syriaca, Calotropis procera, Gigantea } \\
\text { Polypropylene }\end{array}$ & Thermal & $\begin{array}{c}40.16 \mathrm{~g} / \mathrm{g} \text {-Heavy oil } \\
23.00 \mathrm{~g} / \mathrm{g} \text {-Diesel }\end{array}$ & {$[50]$} \\
\hline Ganoderma applanatum mushroom & PFOCTS* & $1.8-3.1 \mathrm{~g} / \mathrm{g}-\mathrm{Oil}$ & [62] \\
\hline Calotropis procera & In natura & $74.04 \mathrm{~g} / \mathrm{g}$-Petroleum & This research \\
\hline Calotropis procera & Thermal & $124.60 \mathrm{~g} / \mathrm{g}$-Petroleum & This research \\
\hline
\end{tabular}

In a generic way, Table 1 shows that the sorption capacity of oils and organic solvents for the sorbent materials that suffered a thermal processes presented better results. It is possible to attest that thermally treated Calotropis Procera is a sorbent material that has a high sorption capacity, for the crude oil (viscosity was $\eta=73.6 \mathrm{cP}$ ) used in this research. The characteristics of the oil, such as the viscosity, is a parameter of great importance in the sorption process, because decrease in the viscosity of the oil reduces absorption within the pores and capillary vessels of the materials, and more viscous oils have greater sorption due to adhesion to the surfaces of the materials and inside the pores. Teas et al. (2001) evidenced the role of viscosity in sorption processes, studying how different viscosities of oils promoted varied results, depending on the type of sorbent material that was evaluated [63]. 
Wei et al. (2003) showed that increased viscosity was able to increase crude oil sorption capacity in different sorbents [9].

Considering the excellent results of this study on the sorption obtained for oil, the sorption of diesel, marine diesel, motor lubricant oil, used lubricating oil, and benzene in the CPT200 conditions compared with $\mathrm{CP}$ was also investigated, in the optimum time of $1440 \mathrm{~min}$ sorption in both dry and layer systems, as shown in Figure 6.
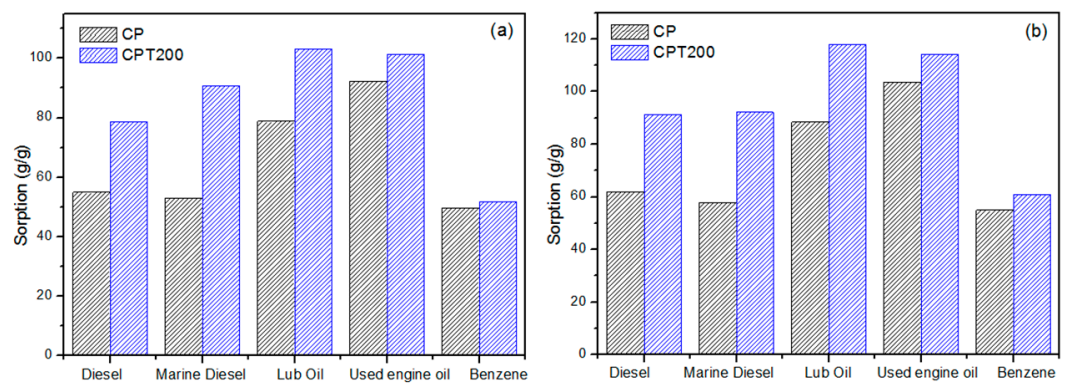

Figure 6. (a) Dry and (b) layer oil sorption test comparing CP and CPT200 for the time of $1440 \mathrm{~min}$.

One can observe in Figure 6a that the dry test for the CPT200 fiber presented a higher sorption capacity $(51.75-103.03 \mathrm{~g} / \mathrm{g}$ ) than the CP for all oils and solvents that were tested. Similarly, the same behavior was verified in the layer system, shown in Figure 6b, in which the CPT200 presents sorption from 60.91 to $117.98 \mathrm{~g} / \mathrm{g}$.

Karan et al. (2011) [64] highlight in their studies that the oil viscosity is a parameter of great importance in the sorption process, and that the decrease of the oil viscosity reduces the sorption within the pores and capillary vessels. Thus, more viscous oils have higher sorption values due to adhesion on the surfaces of the materials and within the pores. Therefore, Figure 6 shows the predicted results: Lower sorption of diesel, marine diesel, and benzene compared to lubricating oils show that the more viscous the oil, the greater the sorption trend by the greater amount of oil to be sorption by the $\mathrm{CP}$ and CPT200 fibers.

Figure 7 shows the possibility of fiber recycling. The resorption capacity of the CPT200 for six cycles was $40.47 \%$ oil when compared to the initial sorption. However, until the third cycle the CPT200 obtained a resorption capacity greater than $60 \%$, demonstrating that fiber has reuse potential.

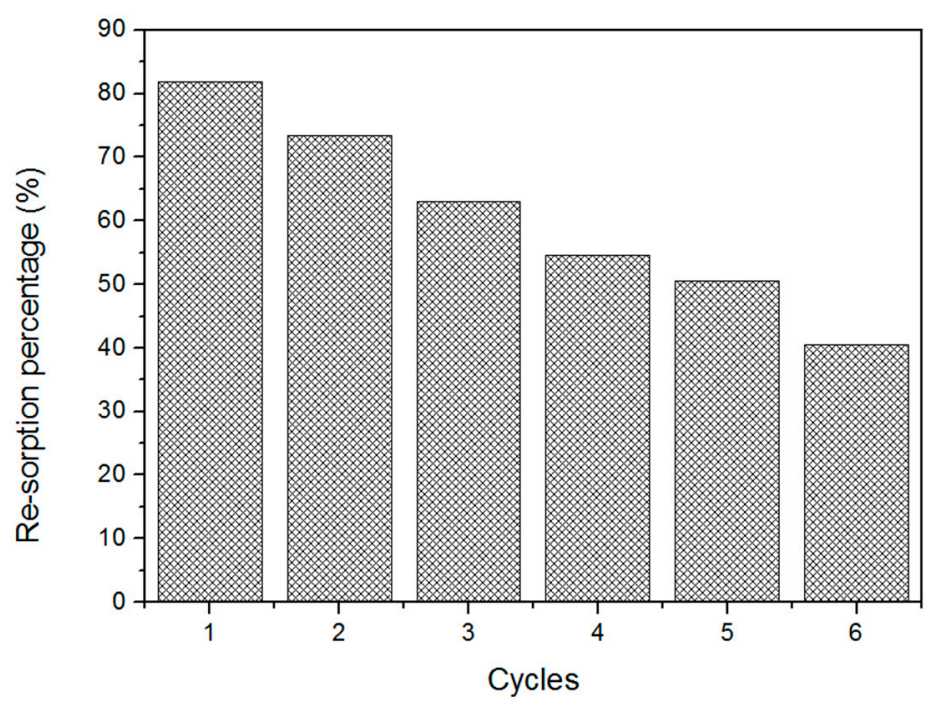

Figure 7. Resorption capacity test for fiber CPT200 in petroleum. 


\subsection{Wettability and Contact Angle}

The wettability of the material surface is determined by the value of the contact angle. In order to verify the hydrophobic and hydrophilic properties of CP, CPT150, and CPT200 fibers, the contact angle for water and oil on the surface of the fibers were measured.

As presented in Figure $8 \mathrm{~d}, \mathrm{e}, \mathrm{f}$, the contact angle for the oil on the surface of fiber CP, CPT150, and CPT200 was $0^{\circ}$, thus, presenting oleophilic characteristics. However, in Figure 8a,b,c, water drops are visible on the surface of CP, CPT150, and CPT200, and the contact angles $(\theta)$ of water reached $128^{\circ}$, $119^{\circ}$, and $114^{\circ}$, respectively, demonstrating hydrophobic properties. For CPT150 and CPT200 there was a decrease in contact angles for water, a consequence of heat treatment and the possible decrease in the cerous surface of the fibers. This was also observed in the infrared spectra (Figure 2) by the decrease in the intensity of the region of $2920 \mathrm{~cm}^{-1}$, referring to the $\mathrm{C}-\mathrm{H}$ stretch.

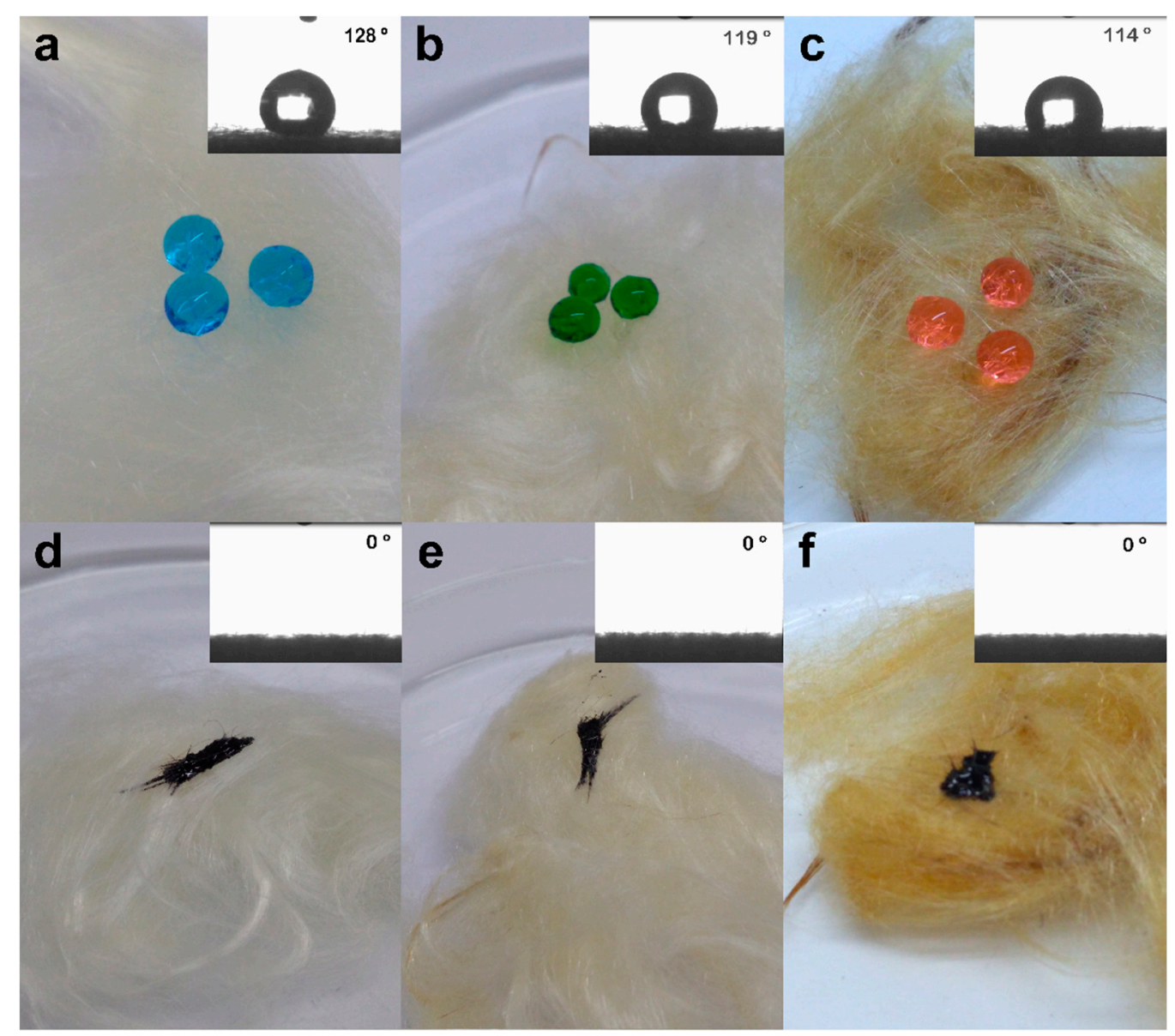

Figure 8. Images of (a) water drop with blue dye and contact angle in $\mathrm{CP}$; (b) water drop with green dye and contact angle in CPT150; (c) water drop with orange dye and contact angle in CPT200; (d) crude oil droplets and contact angle in CP; (e) crude oil droplets and contact angle in CPT150; (f) crude oil droplets and contact angle in CPT200.

As shown in Figure $8 \mathrm{a}-\mathrm{c}$ the water drops with blue, green, and orange dye presented spherical shapes on the fiber surface, while the oil droplets (Figure $8 \mathrm{~d}-\mathrm{f}$ ) spread immediately to the interior of CP, CPT150, and CPT200, demonstrating its excellent hydrophobic and oleophilic properties.

\subsection{Selectivity Test}

Figure 9 shows the process used in the selectivity test to remove the oil from the water using the CP fiber. 


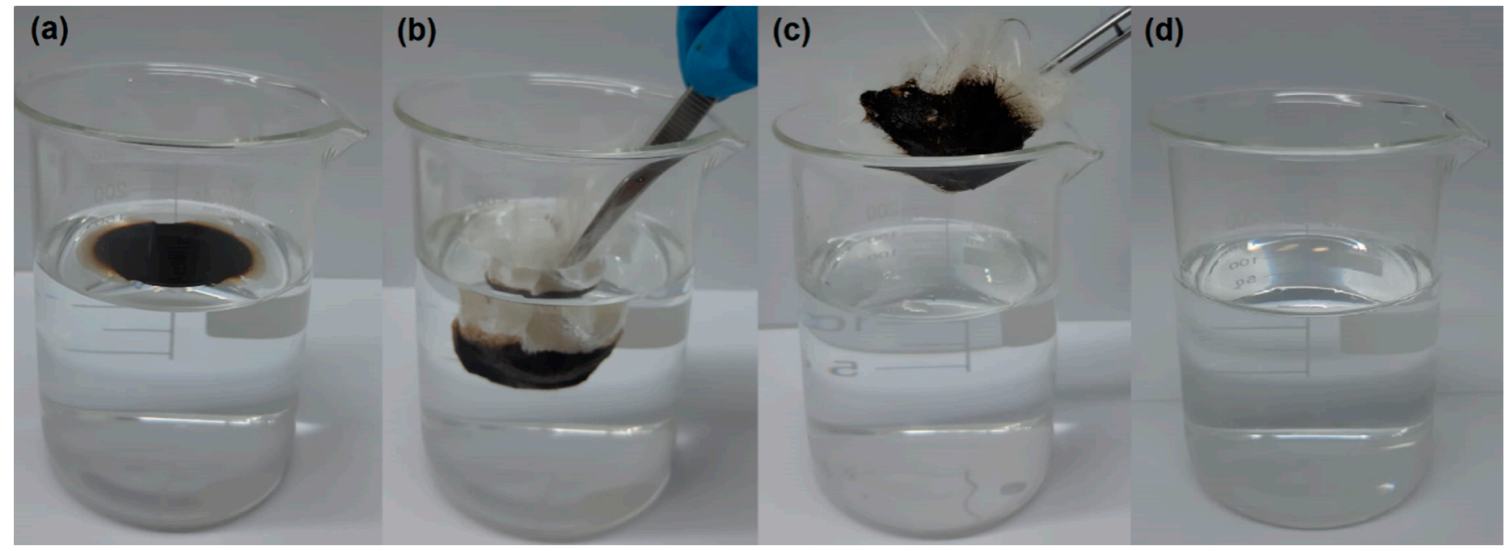

Figure 9. Digital images of oil removal in water (a-c) show oil-water separation using CP as sorbent.

(a) A total of $1 \mathrm{~mL}$ of oil was added into $50 \mathrm{~mL}$ of distilled water to form an oil layer, (b) rapid oil sorption by $\mathrm{CP}$, (c) oil removal sorption by $\mathrm{CP}$, and (d) clean water after oil sorption.

The selectivity test presents the addition of oil into water, forming a film. Then, the CP fiber was placed in contact with the oily surface. One can observe that the $\mathrm{CP}$ carried the petroleum, that is, the oil was selective and completely sorption by the fiber. In addition, it was noted that during the test, the $\mathrm{CP}$ fiber soaked in oil floats on the surface, not sinking in the water, and thus suggesting an excellent oil sorbent and buoyancy.

\subsection{Oil Fixation to the Sorbent}

In order to investigate the oil sorption in the fibers, an optical microscope was used. With the aid of a microsyringe, oil droplets were scattered on the fiber surface, then microscopic images were recorded, as seen in Figure 10.
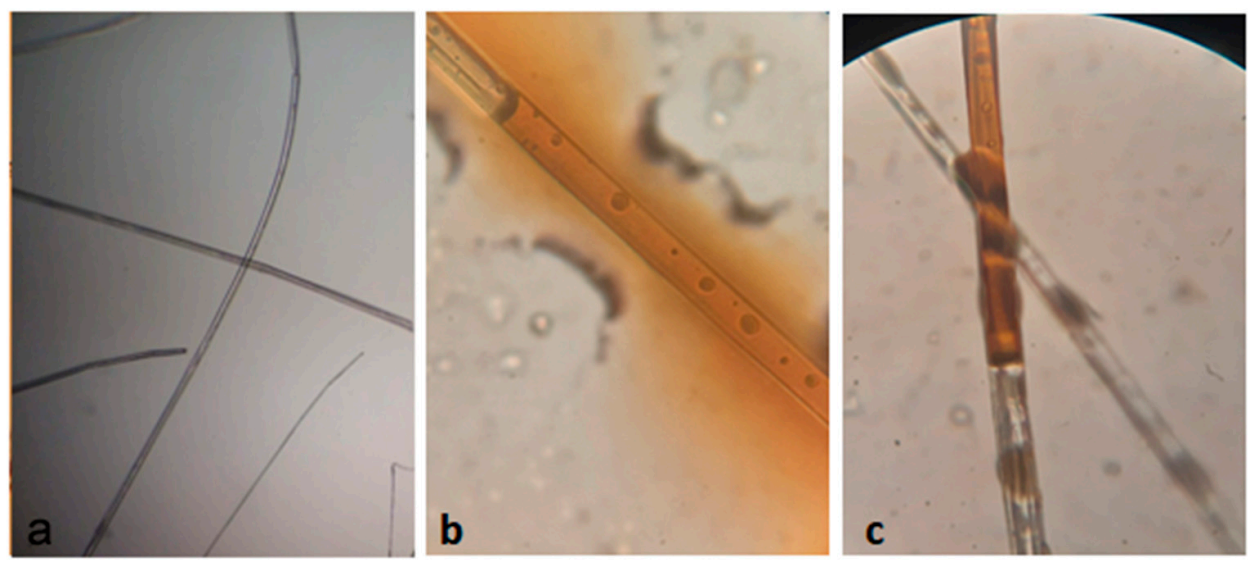

Figure 10. Microscopic images of (a) CP fiber-10×; (b) oil sorption inside the CP lumen-100x; (c) oil trapped between two cross fibers-100x.

Figure 10a presents an empty hollow structure of the lumen by designating to be full of air, allowing the buoyancy of the fiber. In Figure $10 \mathrm{~b}$ one can observe a fiber with absorbed oil inside by capillary action. In Figure 10c it presents two cross fibers forming a firmly connected oily liquid bridge due to adhesive forces (adsorbent component) and due to strong capillary forces (capillary component).

\section{Conclusions}

In summary, the CP, CPT150, and CPT200 fibers showed high hydrophobicity, oilphilicity, and selectivity for petroleum and derivatives, confirmed by the analysis of the contact angle for water and 
crude oil, presenting predominantly hydrophobic surfaces, with $\theta$ of $128^{\circ}, 119^{\circ}$, and $114^{\circ}$ with water, respectively, and $\theta$ of $0^{\circ}$ for crude oil on all fibers. Thermogravimetric analysis in $\mathrm{CP}$ showed thermal stability of up to $213^{\circ} \mathrm{C}$ when the degradation process of the fiber hemicellulose was initiated, followed by cellulose and finally a peak that characterizes lignin decomposition. The FTIR spectra indicated that after the thermal treatments at $150{ }^{\circ} \mathrm{C}$ and $200{ }^{\circ} \mathrm{C}$ there was a slowdown and disappearance of some peaks, which may be correlated with the partial wax removal. The SEM-FEG micrographs revealed the morphology of the surface CP, CPT150, and CPT200 in which there is a hollow structure with lumens that allows the fixation of the oil. However, after the thermal treatment, some shallow grooves were present. The sorption of CP was about 75 times its weight and CTP150 and CPT200 presented crude oil sorption for the dry and layer test $(1440 \mathrm{~min})$ of between $94.31 \mathrm{~g} / \mathrm{g}-103.37 \mathrm{~g} / \mathrm{g}$ and $124.60 \mathrm{~g} / \mathrm{g}-180.95 \mathrm{~g} / \mathrm{g}$, respectively. The CP, CPT150, and CPT200 have an insignificant sorption of water. The performance of sorption tests with other types of oils and solvents in the dry and layer systems with CP and CPT200 resulted in the same behavior profile in which the fiber treated at $200{ }^{\circ} \mathrm{C}$ obtained better sorption capacities in both systems when compared to $\mathrm{CP}$, as observed in the significance of viscosity for the sorption process. In this way, CPT200 can be employed as a promising alternative for the removal of crude oil spills and leaks, due to its good oil/water selectivity, great reuse/resorption capacity, high availability, and excellent sorption property of oils and organic solvents.

Author Contributions: All authors worked on this research. Conceptualization, L.S.H., H.B.d.M.J., and R.B.d.A.; methodology, L.S.H., H.B.d.M.J., and R.B.d.A.; formal analysis, L.S.H. and R.B.d.A.; writing-preparation of the original draft, L.S.H., H.B.d.M.J., and R.B.d.A.; writing-review and editing, D.R.d.S.; supervision, D.R.d.S.; project administration, D.R.d.S.

Funding: Coordenação de Aperfeiçoamento de Pessoal de Nível Superior: FINANCE CODE 001.

Acknowledgments: The authors acknowledge the Coordination for the Improvement of Higher Education Personnel CAPES, the Federal University of Rio Grande do Norte, and the Nucleus of Primary Processing and Reuse of Produced Water and Waste for financial support.

Conflicts of Interest: The authors declare that there is no conflict of interest.

\section{References}

1. Paul, J.H.; Hollander, D.; Coble, P.; Daly, K.L.; Murasko, S.; English, D.; Basso, J.; Delaney, J.; McDaniel, L.; Kovach, C.W. Toxicity and mutagenicity of gulf of Mexico waters during and after the deepwater horizon oil spill. Environ. Sci. Technol. 2013, 47, 9651-9659. [CrossRef] [PubMed]

2. Gros, J.; Nabi, D.; Würz, B.; Wick, L.Y.; Brussaard, C.P.D.; Huisman, J.; van der Meer, J.R.; Reddy, C.M.; Arey, J.S. First day of an oil spill on the open sea: Early mass transfers of hydrocarbons to air and water. Environ. Sci. Technol. 2014, 48, 9400-9411. [CrossRef] [PubMed]

3. Zengel, S.; Montague, C.L.; Pennings, S.C.; Powers, S.P.; Steinhoff, M.; Fricano, G.; Schlemme, C.; Zhang, M.; Oehrig, J.; Nixon, Z.; et al. Impacts of the deepwater horizon oil spill on salt marsh periwinkles (Littoraria irrorata). Environ. Sci. Technol. 2016, 50, 643-652. [CrossRef] [PubMed]

4. Jung, D.; Kim, J.A.; Park, M.S.; Yim, U.H.; Choi, K. Human health and ecological assessment programs for Hebei Spirit oil spill accident of 2007: Status, lessons, and future challenges. Chemosphere 2017, 173, 180-189. [CrossRef]

5. Annunciado, T.R.; Sydenstricker, T.H.D.; Amico, S.C. Experimental investigation of various vegetable fibers as sorbent materials for oil spill. Mar. Pollut. Bull. 2005, 50, 1340-1346. [CrossRef]

6. Ge, J.; Zhao, H.Y.; Zhu, H.W.; Huang, J.; Shi, L.A.; Yu, S.H. Advanced sorbents for oil-spill cleanup: Recent advances and future perspectives. Adv. Mater. 2016, 28, 10459-11049. [CrossRef]

7. Wang, J.; Zheng, Y. Oil/water mixtures and emulsions separation of stearic acidfunctionalized sponge fabricated via a facile one-step coating method. Sep. Purif. Technol. 2017, 181, S183-S191. [CrossRef]

8. Reed, M.; Johansen, O.; Brandvik, P.J; Daling, P.; Lewis, A.; Fiocco, R.; Mackay, D.; Prentki, R. Oil spill modeling towards the close of the 20th century: Overview of the state of the art. Spill Sci. Technol. Bull. 1999, 1, 3-16. [CrossRef]

9. Wei, Q.F.; Mather, R.R.; Fotheringham, A.F.; Yang, R.D. Evaluation of nonwoven polypropylene oil sorbents in marine oilspillrecovery. Mar. Pollut. Bull. 2003, 6, 780-783. [CrossRef] 
10. Prince, R.C. Oil spill dispersants: Boon or bane? Environ. Sci. Technol. 2015, 49, 6376-6384. [CrossRef]

11. Gelderen, L.; Van, L.M.V.; Malmquist, G.J. Vaporization order and burning efficiency of crude oils during in-situ burning on water. Fuel 2017, 191, 528-537. [CrossRef]

12. Ron, E.Z.; Rosenberg, E. Enhanced bioremediation of oil spills in the sea. Curr. Opin. Biotechnol. 2014, 27, 191-194. [CrossRef]

13. Yu, L.; Hao, G.; Xiao, L.; Yin, Q.; Xia, M.; Jiang, W. Robust magnetic polystyrene foam for high efficiency and removal oil from water surface. Sep. Purif. Technol. 2017, 173, 121-128. [CrossRef]

14. Tu, L.; Duan, W.; Xiao, W.; Fu, C.; Wang, A.; Zheng, Y. Calotropis gigantean fiber derived carbon fiber enables fast and efficient absorption of oils and organic solvents. Sep. Purif. Technol. 2018, 192, 30-35. [CrossRef]

15. Ma, Q.; Cheng, H.; Fane, A.G.; Wang, R.; Zhang, H. Recent development of advanced materials with special wettability for selective oil/water separation. Small 2016, 12, 2186-2202. [CrossRef] [PubMed]

16. Pintor, A.M.A.; Vilar, V.J.P.; Botelho, C.M.S.; Boaventura, R.A.R. Oil and grease removal from wastewaters: Sorption treatment as an alternative to state-of-the-art technologies: A critical review. Chem. Eng. J. 2016, 297, 229-255. [CrossRef]

17. Saleem, J.; Riaz, M.A.; McKay, G. Oil sorbents from plastic wastes and polymers: A review. J. Hazard. Mater. 2018, 341, 424-437. [CrossRef]

18. Zhang, A.; Chen, M.; Du, C.; Guo, H.; Bai, H.; Li, L. Poly(dimethylsiloxane) oil absorbent with a three-dimensionally interconnected porous structure and swellable skeleton. ACS Appl. Mater. Interfaces 2013, 5, 10201-10206. [CrossRef]

19. Wu, L.; Li, L.; Li, B.; Zhang, J.; Wang, A. Magnetic, durable, and superhydrophobic polyurethane@Fe O @SiO @fluoropolymer sponges for selective oil absorption and oil/water separation. ACS Appl. Mater. Interfaces 2015, 7, 4936-4946. [CrossRef]

20. Ke, Q.; Jin, Y.; Jiang, P.; Yu, J. Oil/water separation performances of superhydrophobic and superoleophilic sponges. Langmuir 2014, 30, 13137-13142. [CrossRef]

21. Pan, Y.; Shi, K.; Peng, C.; Wang, W.; Liu, Z.; Ji, X. Evaluation of hydrophobic polyvinylalcohol formaldehyde sponges as absorbents for oil spill. ACS Appl. Mater. Interfaces 2014, 6, 8651-8659. [CrossRef] [PubMed]

22. Syed, S.; Alhazzaa, M.I.; Asif, M. Treatment of oily water using hydrophobic nanosilica. Chem. Eng. J. 2011, 167, 99-103. [CrossRef]

23. Seal, S.; Sakthivel, T.; Reid, D.; Goldstein, I.; Hench, L. Hydrophobic high surfasse area zeolites derived from fly ash for oil spill remediation. Env. Sci. Technol. 2013, 47, 5843-5850.

24. Bastani, D.; Safekordi, A.; Alihosseini, A.; Taghikhani, V. Study of oil sorption by expanded perlite at 298.15 K. Sep. Purif. Technol. 2006, 52, 295-300. [CrossRef]

25. Zadaka-Amir, D.; Bleiman, N.; Mishael, Y.G. Sepiolite as an effective natural porous adsorbent for surface oil-spill. Microporous Mesoporous Mater. 2013, 169, 153-159. [CrossRef]

26. Mysore, D.; Viraragavan, T.; Jin, Y. Treatment of oily waters using vermiculite. Water Res. 2005, 39, $2643-2653$. [CrossRef]

27. Adebajo, M.O.; Frost, R.L. Acetylation of raw cotton for oil spill cleanup application: An FTIR and 13C MAS NMR spectroscopic investigation. Spectrochim. Acta A 2004, 10, 2315-2321. [CrossRef]

28. Wang, J.; Zheng, Y.; Kang, Y.; Wang, A. Investigation of oil sorptioncapability of $\mathrm{PBMA} / \mathrm{SiO}_{2}$ coated kapok fiber. Chem. Eng. J. 2013, 223, 632-637. [CrossRef]

29. Wang, J.; Zheng, Y.; Wang, A. Coated kapok fiber for removal of spilled oil. Mar. Pollut. Bull. 2013, 69, 91-96. [CrossRef]

30. Lim, T.; Huang, X. Evaluation of kapok (Ceiba pentandra (L.) Gaertn.) as anatural hollow hydrophobic-oleophilic fibrous sorbent for oil spill cleanup. Chemosphere 2007, 66, 955-963. [CrossRef]

31. Lim, T.; Huang, X. Evaluation of hydrophobicity/oleophilicity of kapok andits performance in oily water filtration: Comparison of raw and solvent-treatedfibers. Ind. Crop. Prod. 2007, 26, 125-134. [CrossRef]

32. Murti, Y.; Yogi, B.; Pathak, D. Pharmacognostic standardization of leaves of Calotropis Procera (Ait) R. Br. (Asclepiadaceae). Int. J. Ayurveda Res. 2010, 1, 14-17. [CrossRef]

33. Nascimento, J.H.O.; Coelho, M.P.G.; Silva, A.P.; Silva, K.K.O.S.; dos Santos, A.R.L.; Campos, C.F.; Morais, J.P.S.; Sivam, R.L. Removal of Crude Oil Using a New Natural Fibre-Calotropis procera. In Natural Fibres: Advances in Science and Technology Towards Industrial Applications; Springer Netherlands: Haarlem, The Netherlands, 2016; pp. 113-125. 
34. Razavi, Z.; Mirghaffari, N.; Rezaei, B. Performance Comparison of Raw and Thermal Modified Rice Husk for Decontamination of Oil Polluted Water. Clean-Soil, Air. Water 2015, 43, 182-190.

35. Anuzyte, E.; Vaisis, V. Natural oil sorbents modification methods for hydrophobicity improvement. Energy Procedia 2018, 147, 295-300. [CrossRef]

36. Husseien, M.; Amer, A.A.; El-Maghraby, A.; Taha, N.A. Experimental Investigation of Thermal Modification Influence on Sorption Qualities of Barley Straw. J. Appl. Sci. Res. 2008, 4, 652-657.

37. Yang, H.; Yan, R.; Chen, H.; Lee, D.; Zheng, C. Characteristics of hemicellulose, cellulose and lignin pyrolysis. Fuel 2007, 86, 1781-1788. [CrossRef]

38. Riegel, I.; Moura, A.B.D.; Morisso, F.P.; Mello, F.S. Análise termogravimétrica da pirólise da acácia-negra (Acacia mearnsii de Wild.) cultivada no rio grande do sul, Brasil. Revista Árvore 2008, 32, 533-543. [CrossRef]

39. Yao, F.W.U.; Lei, Y.; Guo, W.; Xu, Y. Thermal decomposition kinetics of natural fibers: Activition energy with dynamic thermogravimetric analysis. Polym. Degrad. Stab. 2008, 93, 90-98. [CrossRef]

40. Celino, A.; Gonçalves, O.; Jacquemin, F. Qualitative and quantitative assessment of water sorption in natural fibres using ATR-FTIR spectroscopy. Carbohydr. Polym. 2014, 101, 163-170. [CrossRef]

41. Oun, A.A.; Rhim, J.W. Characterization of nanocelluloses isolated from Ushar (Calotropis procera) seed fiber: Effect of isolation method. Mater. Lett. 2016, 168, 146-150. [CrossRef]

42. Boni, H.T.; De Oliveira, D.; Ulson De Souza, A.A.; Ulson De Souza, S.M.A.G. Bioadsorption by sugarcane bagasse for the reduction in oil and grease content in aqueous effluent. Int. J. Environ. Sci. Technol. 2016, 13, 1169-1176. [CrossRef]

43. Likon, M.; Remškar, M.; Ducman, V. Populus seed fibers as a natural source for production of oil super absorbents. J. Environ. Manag. 2013, 114, 158-167. [CrossRef] [PubMed]

44. Barka, N.; Ouzaouit, K.; Abdennouri, M.; El Makhfouk, M. Dried prickly pear cactus (Opuntia ficus indica) cladodes as a low-cost and eco-friendly biosorbent for dyes removal from aqueous solutions. J. Taiwan Inst. Chem. Eng. 2013, 44, 52-60. [CrossRef]

45. Mizi, F.; Dasong, D.; Biao, H. Fourier Transform Infrared Spectroscopy for Natural Fibres. In Fourier Transform-Materials Analysis; Salih, S., Ed.; Intech: London, UK, 2012; Volume 83, pp. 46-68, ISBN 978-953-51-0594-7.

46. Mohebby, B. Application of ATR infrared spectroscopy in wood acetylation. J. Agric. Sci. Technol. 2008, 10, 253-259.

47. Hergert, H.L. Lignins, Occurrence, Formation, Structure and Reaction; Wiley-Interscience: New York, NY, USA, 1971.

48. Zheng, Y.; Cao, E.; Zhu, Y.; Wang, A.; Hu, H. Perfluorosilane treated Calotropis gigantea fiber: Instant hydrophobic-oleophilic surface with efficient oil-absorbing performance. Chem. Eng. J. 2016, 295, 477-483. [CrossRef]

49. Draman, S.F.S.; Daik, R.; Latif, F.A.; El-Sheikh, S.M. Characterization and thermal decomposition kinetics of kapok (Ceiba pentandra L.)- based cellulose. BioResources 2014, 9, 8-23. [CrossRef]

50. Thilagavathi, G.; Karan, C.P.; Das, D. Oil sorption and retention capacities of thermally-bonded hybrid nonwovens prepared from cotton, kapok, milkweed and polypropylene fibers. J. Environ. Manag. 2018, 219, 340-349. [CrossRef]

51. Kalia, S.; Kaith, B.S.; Kaur, I. Pretreatments of natural fibers and their application as reinforcing material in polymer composites-A review. Polym. Eng. Sci. 2009, 49, 1253-1272. [CrossRef]

52. Moriwaki, H.; Kitajima, S.; Kurashima, M.; Hagiwara, A.; Haraguchi, K.; Shirai, K.; Kanekatsu, R.; Kiguchi, K. Utilization of silkworm cocoon waste as a sorbent for the removal of oil from water. J. Hazard. Mater. 2009, 165, 266-270. [CrossRef]

53. Hussein, M.; Amer, A.A.; Sawsan, I.I. Heavy oil spill cleanup using law grade raw cotton fibers: Trial for practical application. J. Pet. Technol. Altern. Fuels 2011, 2, 132-140.

54. Cojocaru, C.; Macoveanu, M.; Cretescu, I. Peat-based sorbents for the removal of oil spills from water surface: Application of artificial neural network modeling. Colloids Surf. A 2011, 1-3, 675-684. [CrossRef]

55. Wang, B.; Karthikeyan, R.; Lu, X.Y.; Xuan, J.; Leung, M.K.H. Hollow Carbon Fibers Derived from Natural Cotton as Effective Sorbents for Oil Spill Cleanup. Ind. Eng. Chem. Res. 2013, 52, 18251-18261. [CrossRef]

56. Zhang, Y.; Yang, S.; Wu, J.; Yuan, T.; Sun, R. Preparation and Characterization of Lignocellulosic Oil Sorbent by Hydrothermal Treatment of Populus Fiber. Materials 2014, 7, 6733-6747. [CrossRef] [PubMed] 
57. Rotaru, A.; Cojocaru, C.; Cretescu, I.; Pinteala, M.; Timpu, D.; Sacarescu, L.; Harabagiu, V. Performances of clay aerogel polymer composites for oil spill sorption:Experimental design and modeling. Sep. Purif. Technol. 2014, 133, 260-275. [CrossRef]

58. Feng, J.; Nguyen, S.T.; Fan, Z.; Duong, H.M. Advanced fabrication and oil absorption properties of super-hydrophobic recycled cellulose aerogels. Chem. Eng. J. 2015, 270, 168-175. [CrossRef]

59. Zheng, Y.; Zhub, Y.Y.; Wangb, A.; Huc, H. Potential of Calotropis gigantea fiber as an absorbent for removal of oil from water. Ind. Crop. Prod. 2016, 83, 387-390. [CrossRef]

60. Cojocaru, C.; Pricop, L.; Samoila, P.; Rotaru, R.; Harabagiu, V. Surface hydrophobization of polyester fibers with poly(methylhydrodimethyl) siloxane copolymers: Experimental design for testing of modified nonwoven materials as oil spill sorbents. Polym. Test. 2017, 59, 377-389. [CrossRef]

61. Cojocaru, C.; Dorneanu, P.P.; Airinei, A.; Olaru, N.; Samoila, P.; Rotaru, A. Design and evaluation of electrospun polysulfone fibers and polysulfone/ $\mathrm{NiFe}_{2} \mathrm{O}_{4}$ nanostructured composite as sorbents for oil spill cleanup. J. Taiwan Inst. Chem. Eng. 2017, 70, 267-281. [CrossRef]

62. Balzamo, G.; Singh, N.; Wang, N.; Vladisavljevi'c, G.T.; Bolognesi, G.; Mele, E. 3D Arrays of Super-Hydrophobic Microtubes from Polypore Mushrooms as Naturally-Derived Systems for Oil Absorption. Materials 2019, 12, 132. [CrossRef]

63. Teas, C.; Kalligeros, S.; Zanikos, F.; Stournas, S.; Lois, E.; Anastopoulos, G. Investigation of the effectiveness of absorbent materials in oil spills clean up. Desalination 2001, 140, 259-264. [CrossRef]

64. Karan, C.P.; Rengasamy, R.S.; Das, D. Oil spill cleanup by structured fibre assembly. Indian J. Fibre Text. Res. 2011, 36, 190-200.

(C) 2019 by the authors. Licensee MDPI, Basel, Switzerland. This article is an open access article distributed under the terms and conditions of the Creative Commons Attribution (CC BY) license (http://creativecommons.org/licenses/by/4.0/). 